Article

\title{
How to Improve Sustainability Competences of Teacher Training? Inquiring the Prior Knowledge on Climate Change in Primary School Students
}

\author{
Carmen Solís-Espallargas *(D) and Hortensia Morón-Monge $\mathbb{D}$ \\ Facultad de Educación, Universidad de Sevilla, 41013 Sevilla, Spain; hmoron@us.es \\ * Correspondence: carmensolise@us.es; Tel.: +34-955-420-784
}

Received: 5 June 2020; Accepted: 6 August 2020; Published: 12 August 2020

\begin{abstract}
The work is carried out in accordance with the Sustainable Development Goal 13 Climate Action with prospective primary school teachers. The study presented is part of the science education subject at the University of Seville (Spain) during the 2019-2020 academic year. This research has two main goals, on the one hand, to present an innovative educational experience (design and implementation) for teacher training, on the other hand, to assess the educational implication of the experience from the prospective primary school teachers' self-perception about their level of sustainability competences achieved. The novel educational experience consisted in the inquiry of prior knowledge about climate change in primary school children for the design of a lesson plan. The degree of scope of the educational experience, in particular, the level of sustainability competences achieved was assessed from the self-perception of the participants (Prospective Primary school Teachers) through a Likert-type questionnaire. The results show an improvement in the degree of acquisition of these competences, not only from their self-perception, but also from the investigative process followed through this innovative experience. Likewise, these results indicate the success of the educational proposal as a possible educational strategy for the sustainability of the curriculum in the field of science education.
\end{abstract}

Keywords: teacher training; primary education; competencies in sustainability; perception; climate change

\section{Introduction}

We live in a world marked by great problems and socio-environmental inequalities. The recent global health crisis of COVID-19 is not an isolated case, but is an effect of this planetary imbalance in which the pandemic is showing us the need to do things differently. The climate crisis will not give us the opportunity to stay two months at home and then return to normal. Nor will there be a vaccine to prevent climate change and its consequences.

We are in a climate emergency situation, as announced in 2015 by the UN in the 2030 Agenda on Sustainable Development within the Goal 13 Climate Action and in the latest international events (Climate Action Summit 2019 and Climate Summit of Madrid 2019). It has also been vindicated by citizens through the Fridays for future youth movement led by the young Greta Thunberg as an environmental activist. It is not enough to know the environmental problem, but it is the moment to act, from the putting into play of competences that reflect both professionally and personally the commitment to sustainability [1].

As teacher educators, we believe it is necessary to address these issues with our prospective primary school teachers (onwards PPT). In this sense, with this study, we focus on the urgency of training in sustainability skills with these students due to the cascade effect that their profession has 
on society. Likewise, it is necessary that we analyze which are the most appropriate lesson plans for the development of sustainability competencies. The design of educational proposals must, in turn, be accompanied by evaluation instruments that allow us to objectively and systematically assess the scope of said proposals. In our case, it will be assessed based on the students' self-perception of their degree of acquisition of the sustainability skills achieved.

Therefore, our research has two main goals. First, to present an innovative educational experience based on education for sustainability approach. Second, after completing the educational experience, to assess the level of scope of the proposal from the PPT's self-perception of their competencies in sustainability. For that, we present a case study with PPT. This research is part of EDINSOST project (Education and Social Innovation for Sustainability) and other related studies on training in Sustainability in Higher Education [2]. So, this work intends to complement this background.

However, what do we understand by competencies? Particularly, what do we understand by sustainability competencies from the educational field of higher education, and what other educational proposals in higher education are being made around this issue? We address these issues in the following sections in order to justify our study.

\subsection{Competences in the Educational Curriculum and Teacher Training}

The concept of competence is a recent insertion in the educational curriculum. Its conceptual complexity and the different conceptualizations in the legislation of each country and European and international reports, make this an imprecise and often ill-defined concept [3-5].

For the OECD [6] "key competencies involve the mobilization of cognitive and practical skills, creative skills and other psychosocial resources such as attitudes, motivation and values". In the European Framework of Reference [7] it defines it as "a combination of knowledge, capacities and attitudes appropriate to the context" and establishes "the key competences for lifelong learning, with which people can achieve their personal fulfillment and development, thus as for active citizenship, social inclusion and employment".

We can find multiple references on the importance of developing a competency-based curriculum for the contextualization of knowledge [5]. Some examples are the concepts of "lifelong learning" [8] or from science education "science literary" and "scientific literary" [9]. In this framework, we find the PISA report (Program for International Student Assessment) and the SISCON and SATIS projects of the ASE (Association for the Sciences of Education) in the 1980s, which emphasize the importance of science education from real problems or contexts [10].

In the Spanish educational context, the educational competences are included for the first time in the Ley Orgánica de Educación of 2006 (LOE) as "the capacities to apply in an integrated way the contents of each teaching and educational stage, in order to achieve the proper performance of activities and effective resolution of complex problems". Definition that continues to be maintained in the current education law in our country (LOMCE) of 2013.

Regardless of the different conceptualizations offered and nuances of the word competence, we can highlight three distinctive aspects or dimensions to be reached: Knows, Shows How and Shows How and Does, in different contexts for problem solving.

However, previous studies show the difficulty that the future primary school teacher has in understanding what educational competencies are and therefore in designing curricular proposals in accordance with them [5]. To this is added, the particular interpretations made by the textbook publishers of the competitions [11-17].

Bearing in mind this panorama, if the concept of competence itself is recent, ambiguous and presents difficulties for the pre-service teachers in the design of educational proposals, it will not be less difficult to develop sustainability skills for these teachers-in-training 


\subsection{Teaching for Sustainability in Higher Education and Teacher Training}

While progress is being made in defining the key competences in education in general, the conceptualization and development of education for sustainability also progresses and evolves [18]. There is a broad consensus in considering that education for sustainability is based on values of justice, equity, tolerance, sufficiency and responsibility [19].

In 2002, the United Nations proclaimed the period 2005-2014 as the Decade of Education for Sustainable Development, designating UNESCO as the executing agency. In this sense, from higher education from the Conferencia de Rectores de Universidades Españolas (CRUE) the creation of the working group for Environmental Quality and Sustainable Development (2002) is approved. The purposes of this working group are to promote initiatives related to risk prevention, management, participation and environmental awareness in universities, as well as inter-university cooperation in these matters. To do this, a series of guidelines are designed to integrate the design and development of curricular content in higher education.

These initiatives are favored thanks to the creation of the European Higher Education Area (EHEA) offering a great opportunity to introduce and promote sustainability criteria in higher education. Contributing to the sustainable development and exercise of social responsibility of future professionals is one of the goals of the 2015 University Strategy. Projects such as EDINSOST, 2016-2018 (Education and social innovation for sustainability) emerge. Training in Spanish universities of professionals as agents of change to face the challenges of society (within which this research is framed), whose general objective is to advance educational innovation in Development Education in Spanish universities, aims to equip future student graduates with the necessary skills to catalyze change towards a more sustainable society.

The integration of Education for Sustainable Development (ESD) in university higher education contributes to developing sustainability competencies, such as critical and creative thinking, problem solving, capacity for action, collaboration and systemic thinking, in order to train potential change agents capable of configuring more sustainable societies. To achieve these competences, it is necessary to make the curriculum sustainable. This implies empowering the university community, as well as creating spaces for collective, inter and transdisciplinary reflection and collaboration, which promote learning, critical reflection on existing worldviews and practices, and creative and innovative action [20].

Despite the fact that there are many universities committed to introducing Sustainable Development (in the curriculum, research and social projection), there is still a lack of social commitment from the graduates, which also decreases as the students advance in their degree [20].

Some previous studies in higher education oriented to an ESD are the works of Ferrer, Lazo and Pierra [21] and Penagos [22] that justify the need to integrate this theme into university training. Other more recent studies such as the one by Murga-Menoyo [23] present a base proposal for the formation of sustainability competencies, suitable to be adapted to circumstances, levels and different student profiles. From the Service Learning approach, we highlight the proposals of [24] and Aramburuzabala, Cerrillo and Tello [25] as a way to make the curriculum more sustainable in higher education. Likewise, from a theoretical approach the proposal of Novo and Murga-Menoyo [26] for the curricular sustainability, and from a methodological approach the work of Azcárate, Navarrete and García González [27] are highlighted.

Other studies aimed at teacher training are Manzanares, Fuentes and Manzanares [28] which present a teaching experience focused on sustainable development, based on teaching objectives, but not on competencies. Particularly from a competence perspective, the works Albareda-Tiana, García-González, Jiménez-Fontana and Solís-Espallargas [29] show different active teaching-learning strategies: problem-based learning, project-oriented learning and a cross-disciplinary workshop to promote the integration of education for sustainable development and measure the level of acquisition of several competencies of sustainability.

Other research [30] evaluates the degree of curricular sustainability of an educational proposal made with the participants. In the same way, the perceptions and views of a group of student teachers 
in relation to education for sustainable development competencies are explored, using as a research instrument a questionnaire [18,31]. From the early childhood education degree, Cantó [32] inquires into the perception of the participants about the importance of sustainability in their training and their knowledge on this subject. As we see in this bibliographic background, more and more works are becoming important for their contributions to the field of curriculum sustainability in higher education. A path that needs to continue enriching itself with new contributions and evaluations of successful proposals that help us continue to make our subjects more sustainable.

\subsection{Education for Sustainability and Science Education from Socio-Scientific Issues}

As we can see in the previous studies, there are more and more proposals to make the curriculum sustainable in the university and even aimed at our study group, such as the training of the primary school teacher. However, more specific studies are lacking that serve us as teachers as examples of proposals to make the curriculum more sustainable from our areas of study. In particular, we as teachers in the area of science education need proposals or studies that help us integrate ESD from our subjects that make up the grade of primary teacher. For this reason, we ask ourselves how to integrate the perspective of ESD from our subject, such as science education? To what extent does the perspective of science education facilitate (or hinder) curricular sustainability?

ESD promotes a vision of education for empowerment (participatory, affective, multicultural, dialogical, democratic, investigative, interdisciplinary and activist) [33]; it can lead students to become workers, workers, thoughtful citizens and, therefore, social critics and agents of change. This is extremely important in the social, economic, health and environmental moments that we are currently experiencing.

Science education is not kept out of these questions in its educational purpose for citizen scientific literacy and there are examples of training aimed at action for the resolution of different socio-scientific issues [33-35,35-39]. Facing these problems requires your understanding, making decisions and acting, from a curriculum approach oriented to citizen activism [40,41]. Science teaching and learning must move away from the simple acquisition of scientific content and concepts and be organized around problematic issues for society (climate change, human health, land, water and mineral resources, food and agriculture; energy resources, consumption and sustainability levels; industry; transport and communication technologies; ethics and social responsibility) [40,42].

Institutions such as the National Research Council, 2001, and international reports such as Rocard, 2007 and national reports such as ENCIENDE [43] recommend teaching real and everyday science in a way that is useful for the day-to-day life of students.

In this sense, educational projects such as the "We Act"-Promoting Collective Activism on Socio-Scientific Issues [34] promote this type of methodology and educational perspective of science teaching in active primary school teachers and university teachers.

Last but not least, we have to point out the important role of emotions roll for teaching-learning processes and for environmental awareness. Working from the students' emotions can improve the development of sustainability skills. In this sense, the studies by Ramkissoon and Smith [44] and Ramkissoon, Mavondo and Uysal [45] show the importance of emotions and environmental worldview to engage people with their environment promoting conservationist attitudes and the construction of knowledge.

Therefore, a science education from this activist and interdisciplinary perspective allows integrating and complementing an ESD for citizen scientific literacy. It is just this vision of science education that we promote with the innovative proposal that we present here, namely, an educational proposal based on school inquiry about environmental issues such as climate change and the prior knowledge of primary school children. Our objective is that, based on the experience gained, teachers in training develop sustainability competencies. 
For this reason, this work presents a case study about the innovative proposal, as well as the evaluation instruments to assess its level of contribution to the development of sustainability competencies.

\section{Materials and Methods}

Our research methodology is based on a case study, action research model [46-49]. This is characterized by studying a specific case with the intention of understanding and improving teaching-learning processes.

As we previously introduced, we want to improve the sustainability competencies of our PPT from science education. For that, we designed an innovative teaching experience based on sustainability competences. In this teaching experience our PPT have to inquire as to the primary school students' prior knowledge about Climate change. To resolve these issues, we ask this main research question:

How can we improve sustainability competencies of Prospective Primary school teachers?

Answering this main question, in turn allows us to assess to what extent the educational proposal designed has made our subject sustainable, as a sub-question. To assess its educational implications, we use as a main instrument a questionnaire (Likert scale) among other. As a summary, Figure 1 represents the outline of the different questions addressed in the research.

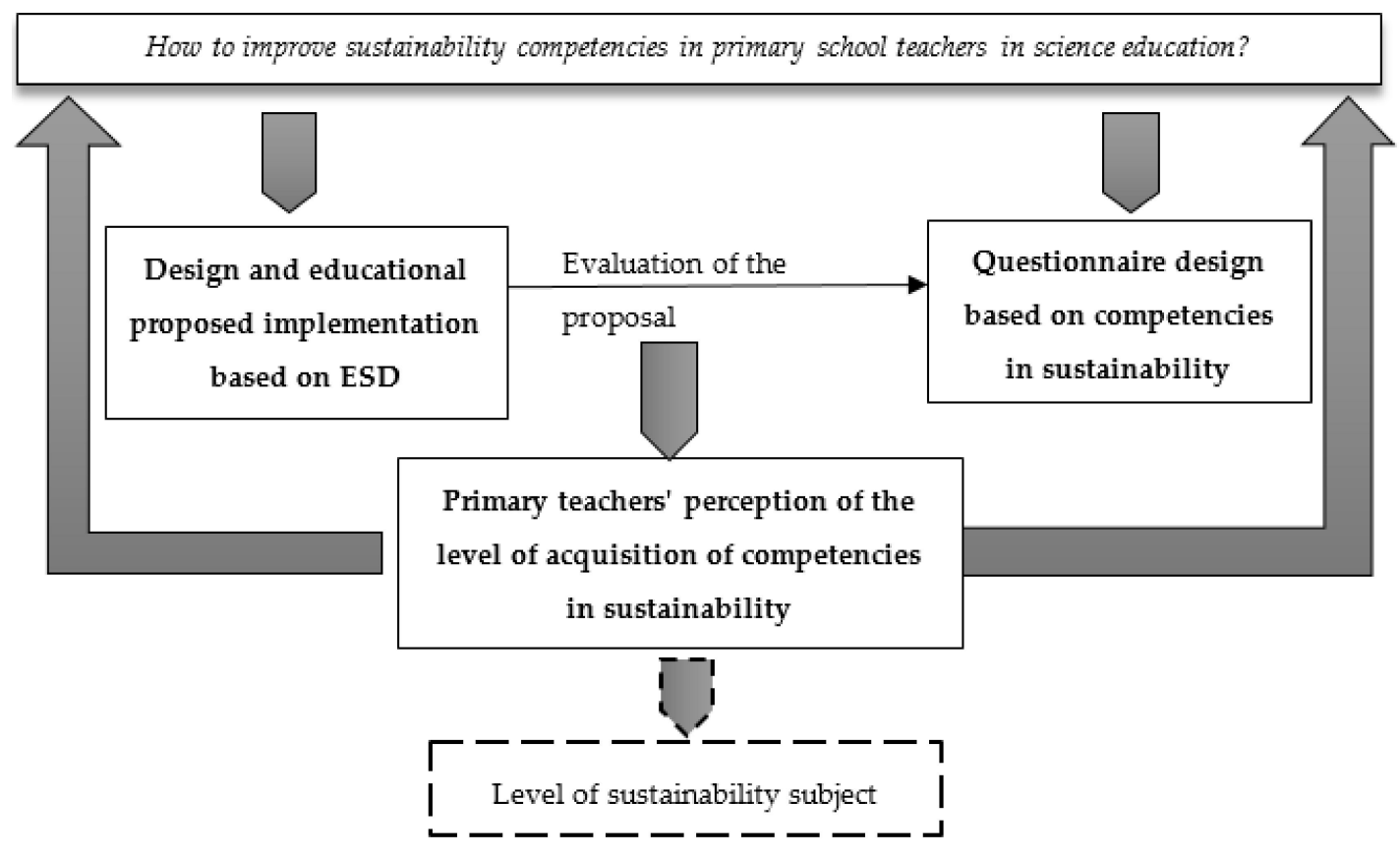

Figure 1. Outline of the investigation. Goal and main research question.

\subsection{Participants}

The case study was developed during the 2019-2020 academic year. A total of 54 students of the Degree in Primary Education at the University of Seville, Spain have participated. The participants, PPT, were duly informed and gave their consent regarding collecting their data anonymously; 50 students $(92.6 \%)$ were girls and $4(7.4 \%)$ were boys.

\subsection{Data Collection Instruments}

In this research, a questionnaire was used to measure self-perception on the level of acquisition of sustainability competencies of PPT. 
Description of the Questionnaire and Rubric on Acquisition of Competencies in Sustainability

The questionnaire Self-perception Skills in Sustainability (SQSS) tries to measure the self-perception that PPT have on the level of acquisition of sustainability competencies acquired before and after their participation in the methodological proposal. The questionnaire used is an adaptation of the Questionnaire on the acquisition of skills in sustainability of the EDINSOST project used in other previous research [50,51]. The questionnaire consisting of 12 Likert-type questions is designed to analyze by levels the degree of acquisition of skills in sustainability. These competences are approved by the Conference of Rectors of Spanish Universities (CRUE-CADEP) to be implemented in a cross-curricular manner in all the degrees of the Spanish University System.

The original questionnaire is designed based on the Competencies in Sustainability Map for education degree [52]. The use of a Map of competences places us in an approach of the evaluation of the methodological proposal oriented to learning; that is to say, an evaluation understood as "a process interrelated with learning ( ... ) that can, by itself, promote the development of useful and valuable competences for the academic present and future work" [53], in line with the approaches of education for sustainability. In a practical way, it facilitates the quality of the training process by establishing concrete indicators of achievement, backed by evidence, relatively easy to verify; one of the main difficulties faced by teachers in the context of training of competencies for sustainability [23].

In the same way that we have adapted the questionnaire to evaluate the proposal, we have adapted the competency map to analyze the data from the questionnaire (sustainability competence assessment rubric). Adaptation from [54] is based on the elimination of the SUST3 competition since it does not proceed in this project and on the adaptation of some of the competence, units focusing on Climate change (see Table 1). The three levels of the table are composed of learning outcome (LO) that are of increasing difficulty and reflect the operations that the subjects learn to handle: knows, knows how, and shows how and does. These three levels are proposed from the pyramid of Miller [55]: Level 1 know - at the base of the pyramid this corresponds to knowledge and refers to learning, Level 2 Knows how - this level corresponds to integration and development in a situation and Level 3 Shows how and does-this is related to showing competency during action and the possibility of transferring that action (reference level).

From the rubric of competencies in sustainability, we will use the following evaluation instrument for the questionnaire responses (Table 2). Each student must assess their level of acquisition according to the scale at each level of competence: none (N0), low (N1), medium (N2), high (N3).

A summary of the research process is presented in the following Table 3. 
Table 1. Sustainability competence assessment rubric. Adaptation from Competency map on sustainability in education at the university level [54] within the framework of the Education and Social Innovation for Sustainability (EDINSOST) project.

\begin{tabular}{|c|c|c|c|}
\hline \multicolumn{4}{|c|}{ Sustainability Competence Assessment Rubric } \\
\hline \multicolumn{4}{|c|}{ Learning Outcomes } \\
\hline & Level 1: Knows & Level 2: Knows How & Level 3: Shows How and Does \\
\hline $\begin{array}{l}\text { SUST 1-Critical contextualization of } \\
\text { knowledge establishing interrelationships } \\
\text { between social, economic, environmental, } \\
\text { local, and/or global problems }\end{array}$ & $\begin{array}{l}\text { 1.1. Knows the functioning of natural, social, and } \\
\text { economic systems and how Climate change } \\
\text { influences them. } \\
\text { 1.2. Knows the procedures and resources to } \\
\text { integrate sustainability into educational projects. }\end{array}$ & $\begin{array}{l}\text { Analyzes and understands the relationship between } \\
\text { natural systems and social and economic systems } \\
\text { and how Climate change influences them. } \\
\text { Understands and takes advantage of the } \\
\text { opportunities that present themselves in educational } \\
\text { contexts in order to plan sustainable projects. }\end{array}$ & $\begin{array}{l}\text { Is able to imagine and predict the impacts the Climate } \\
\text { change produce in natural, social and economic systems } \\
\text { Provides critical and creative solutions from an } \\
\text { educational project to the problem of Climate change. }\end{array}$ \\
\hline $\begin{array}{c}\text { SUST 2-Sustainable use of resources in the } \\
\text { prevention of negative impacts on natural and } \\
\text { social environments }\end{array}$ & $\begin{array}{c}\text { Has basic knowledge of identifying possible } \\
\text { socio-environmental impacts derived from } \\
\text { educational actions }\end{array}$ & $\begin{array}{l}\text { Knows how to develop educational actions that } \\
\text { mitigate negative socio-environmental impacts }\end{array}$ & $\begin{array}{l}\text { Designs and develops educational activities in which } \\
\text { negative socio-environmental impacts are taken into } \\
\text { account and incorporates mitigating measures }\end{array}$ \\
\hline $\begin{array}{l}\text { SUST 4-Application of ethical principles } \\
\text { related to sustainability values in personal and } \\
\text { professional behavior }\end{array}$ & $\begin{array}{l}\text { Knows the ethical principles of sustainability and } \\
\text { the importance of respecting diversity in } \\
\text { educational intervention }\end{array}$ & $\begin{array}{l}\text { Understands and integrates the ethical principles of } \\
\text { sustainability in his/her actions, considering nature } \\
\text { as a good in itself and transmitting the importance of } \\
\text { education for a change in the relationship between } \\
\text { human beings and the socio-cultural environment }\end{array}$ & $\begin{array}{l}\text { Is able to design and/or manage educational projects } \\
\text { taking into account ecological ethics to improve quality } \\
\text { of life and to promote the common good }\end{array}$ \\
\hline
\end{tabular}

Table 2. Questionnaire assessment tool.

\begin{tabular}{|c|c|c|c|}
\hline \multirow{3}{*}{$\begin{array}{l}\text { Sustainability Competencies Approved by the CRUE } 2012 \text { and Adapted } \\
\text { for Education by EDINSOST } 2018\end{array}$} & \multicolumn{3}{|c|}{ Level of Acquisition of the Competency Learning Outcomes } \\
\hline & Level 1 Knows & Level 2 Knows How & Level 3 Shows How and Does \\
\hline & N0-N3 & N0-N3 & N0-N3 \\
\hline $\begin{array}{l}\text { SUST 1-Critical contextualization of knowledge establishing } \\
\text { interrelationships between social, economic, environmental, local, and/or } \\
\text { global problems } \\
\text { SUST 2-Sustainable use of resources in the prevention of negative impacts } \\
\text { on natural and social environments } \\
\text { SUST 4-Application of ethical principles related to sustainability values in } \\
\text { personal and professional behavior }\end{array}$ & & & \\
\hline
\end{tabular}

Table 3. Research design summary.

Method

1. Development of the questionnaire before and after participation in the experience

$$
\text { 2. Data analysis }
$$

3. Final data
Tool

Questionnaire SQSS (Self-perception Skills in Sustainability)

Sustainability competence assessment rubric

Questionnaire assessment tool 


\section{Methodological Proposal: Study of the Prior Knowledge of Primary School Children on Climate Change for the Design of Teaching Lesson}

\subsection{Description and Development of the Educational Experience}

This proposal is developed within the framework of the Science education subject in the Primary Education Degree of the University of Seville (Spain) during the 2019-2020 academic year. Its objective is the training in specific competences of the professional practice of primary science teachers oriented towards sustainability. For this, PPT are proposed to carry out research on the prior knowledge that primary school girls and boys have about the problem of climate change, for a subsequent design of a teaching proposal adapted to the primary class group on the one who is investigating. The complete development of this proposal has had a total duration of 8 months of work.

These are six different phases of work:

1. Training. Firstly, the PPT carried out an awareness and training workshop on the problem of climate change. Do I feel informed/sensitized about the problem of climate change for this research? The causes and consequences of climate change were approached from a socio-scientific perspective and connected with the events that are taking place locally and internationally (World Strike for Climate 2019, World Summit for Climate Madrid 2019, Fridays for future movement, etc.).

2. Selection of school and course to carry out the research. The PPT were divided into groups of four people, which make up the research teams. Each team selected a school and a course between the 2nd and 3rd cycles of primary school.

3. Questionnaire design. Each working group made a proposal on what prior knowledge they wanted to inquire about in relation to Climate change. This proposal was accompanied by a bibliographic review of other related research. The proposals were grouped and in the class group a selection was made together with the teacher of the questions asked. The questionnaire was validated by experts and a pilot test was carried out on a class of 20 2nd cycle primary students and 203 rd cycle primary students. The questionnaire was previously completed by the PPT themselves to know and explain their own ideas about what they were going to inquire about.

4. Intervention. The PPT went in groups to the previously selected schools. They explained the questionnaire instructions to the primary school students and collected the data.

5. Data analysis. The working groups proposed analysis categories for the organization of the data and a common system of categories (heading) was agreed. Each group presented the system of analysis followed and the results and conclusions of a question to the whole class, so that the methodology of analysis of each question was debated and agreed. Each group presented the conclusions of a question in the questionnaire.

6. Design of the teaching proposal. Once the conclusions on the main ideas that children have about climate change were obtained, each group proceeded to design a teaching proposal on Climate change adapted to each primary class. To do this, they established competences, objectives, contents as well as a sequence of activities and the evaluation to know the achievement, within the framework of a school research methodology.

\subsection{Products Obtained as a Result of the Educational Experience}

\subsubsection{Prior Knowledge Questionnaire on Climate Change}

The first product is the questionnaire designed for research on children's ideas about Climate change. It consists of 9 questions organized in 4 content blocks. The PPT have carried out the questionnaire to a total of 355 primary, 3rd, 4th, 5th and 6th grade students, aged between 8 and 13, distributed in 16 schools in the province of Seville (Spain). 


\subsubsection{Prior Knowledge Analysis Rubric on Climate Change}

Given the abundance of information that is collected in a questionnaire, it becomes necessary to analytically approach the information through an emerging category system based on the analysis of the data. In this way, the PPT jointly developed a rubric to categorize the ideas collected. The rubric has two methods of data organization: (a) open questions by frequency of a limited number of more or less common ideas within the speeches that boys and girls construct, and (b) category system organized by levels of complexity that it offers an approximation on the individual and group level in which the class finds itself in relation to each question.

\subsubsection{Analysis Report of the Prior Knowledge of Primary School Students on Climate Change}

After analyzing the data from the questionnaire using the rubric, the PPT prepared a team report with the analysis and results in the form of conclusions and teaching objectives from the research carried out at their school.

\subsubsection{Design of Educational Proposals on Climate Change}

From the data obtained on the prior knowledge that primary school students have on Climate change in the form of difficulties and learning objectives, each team designed a teaching proposal on climate change adapted to the reality of each primary classroom, obtaining a total of 14 teaching proposals to work on the problem of climate change aimed at students from 8 to 13 years of primary school.

\section{Results}

\section{Results of the Assessment of Competencies of Sustainability}

From the instrument created for the evaluation of the questionnaire (Table 2) we show the data of the questionnaire completed by the PPT organized by frequencies before and after participation in the methodological proposal. The highest frequencies are marked in the Tables 4 and 5 .

A first analysis of the results shows an increase in the number of students who go from N0 and N1 (little/low) to N2 and N3 (medium/high) in each of the levels of the Miller scale of each of the competitions. This shows a positive perception of the students regarding the achievement of learning.

Before participating in the teaching proposal, the majority of students were classified as N1 in the three sustainability competences, with the exception of the SUST1.1 Level 3 competition in which the students were between an N1 and an N2 for the acquisition of competencies. The N3 is found at a frequency of less than 5 students.

Table 4. Questionnaire data in terms of frequency of prospective primary school teachers (PPT) before their participation in the experience.

\begin{tabular}{ccccccccccccc}
\hline Before & \multicolumn{3}{c}{ Level 1 Knows } & \multicolumn{4}{c}{ Level 2 Knows How } & \multicolumn{3}{c}{ Level 3 Shows How and Does } \\
\hline & N0 & N1 & N2 & N3 & N0 & N1 & N2 & N3 & N0 & N1 & N2 & N3 \\
\hline SUST 1.1 & 3 & 42 & 7 & 2 & 13 & 32 & 8 & 1 & 3 & 23 & 27 & 1 \\
\hline SUST 1.2 & 21 & 24 & 8 & 1 & 16 & 31 & 7 & 0 & 19 & 25 & 10 & 0 \\
\hline SUST 3 & 12 & 31 & 11 & 0 & 11 & 27 & 16 & 0 & 17 & 25 & 12 & 0 \\
\hline SUST 4 & 12 & 24 & 13 & 5 & 4 & 34 & 13 & 3 & 20 & 27 & 7 & 0 \\
\hline
\end{tabular}

Table 5. Questionnaire data in terms of PPT frequency after participation in the experience.

\begin{tabular}{ccccccccccccc}
\hline After & \multicolumn{4}{c}{ Level 1 Knows } & \multicolumn{4}{c}{ Level 2 Knows How } & \multicolumn{3}{c}{ Level 3 Shows How and Does } \\
\hline & N0 & N1 & N2 & N3 & N0 & N1 & N2 & N3 & N0 & N1 & N2 & N3 \\
\hline SUST 1.1 & 0 & 0 & 25 & 29 & 0 & 0 & 29 & 25 & 0 & 1 & 8 & 45 \\
\hline SUST 1.2 & 0 & 2 & 22 & 30 & 0 & 2 & 25 & 29 & 0 & 1 & 20 & 33 \\
\hline SUST 3 & 0 & 3 & 27 & 24 & 0 & 1 & 21 & 32 & 0 & 1 & 27 & 26 \\
\hline SUST 4 & 0 & 5 & 22 & 27 & 0 & 3 & 31 & 20 & 0 & 2 & 25 & 27 \\
\hline
\end{tabular}


It is significant that there is no student who, after participating in the teaching proposal, is placed in a N0 at any level of each competition, a fact that did occur before the experience.

Below in the Figures $2-5$ it is presented the comparative analysis according to each of the levels of each competence:

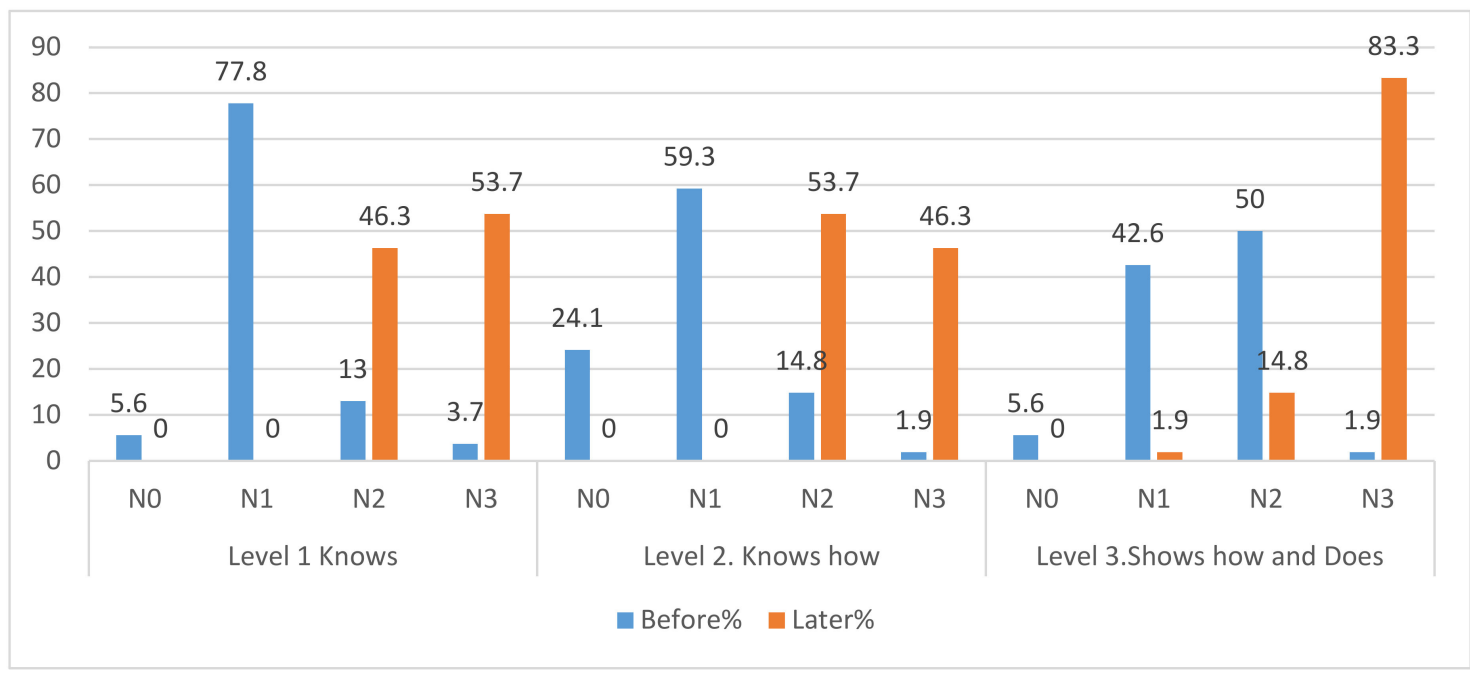

Figure 2. UST 1.1-Critical contextualization of knowledge establishing interrelationships between local and/or global social, economic, and environmental, problems.

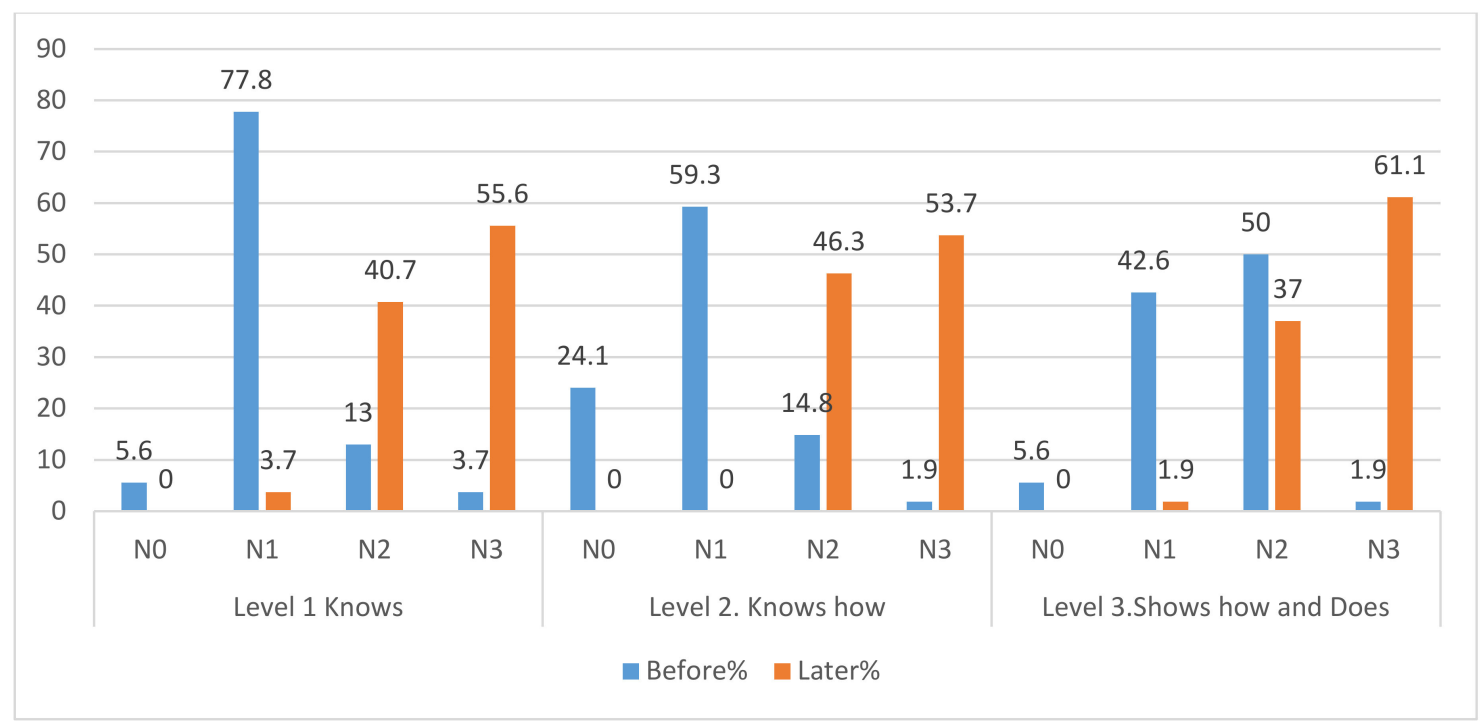

Figure 3. SUST 1.2.-Critical contextualization of knowledge establishing interrelationships between local and/or global social, economic, and environmental, problems.

We can see in Figure 2 that the SUST 1.1 competency measures three levels of skill acquisition. Each level has a self-perception scale in which the student is assessed before and after their participation in the teaching proposal. The results show that:

At Level 1, which measures the degree of acquisition of the learning outcome "Knows the functioning of natural, social, and economic systems and how climate change influences them", 77.8\% of the students were in grade N1 before the experience. After the intervention, $46.3 \%$ of the students recognized themselves in an N2 and 53.7\% in an N3 category. We highlight that after the intervention, no student is in either N0 or N1, the lowest levels. 


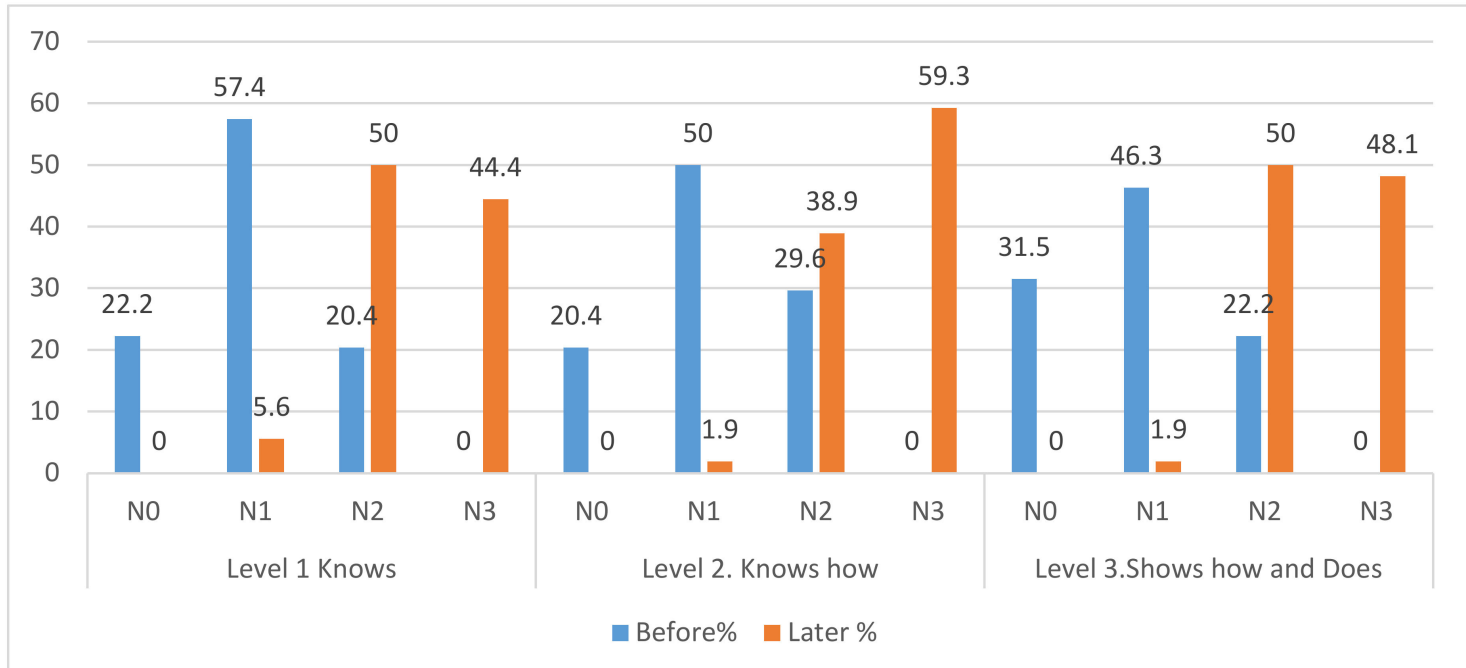

Figure 4. SUST 2-Sustainable use of resources in the prevention of negative impacts on natural and social environments.

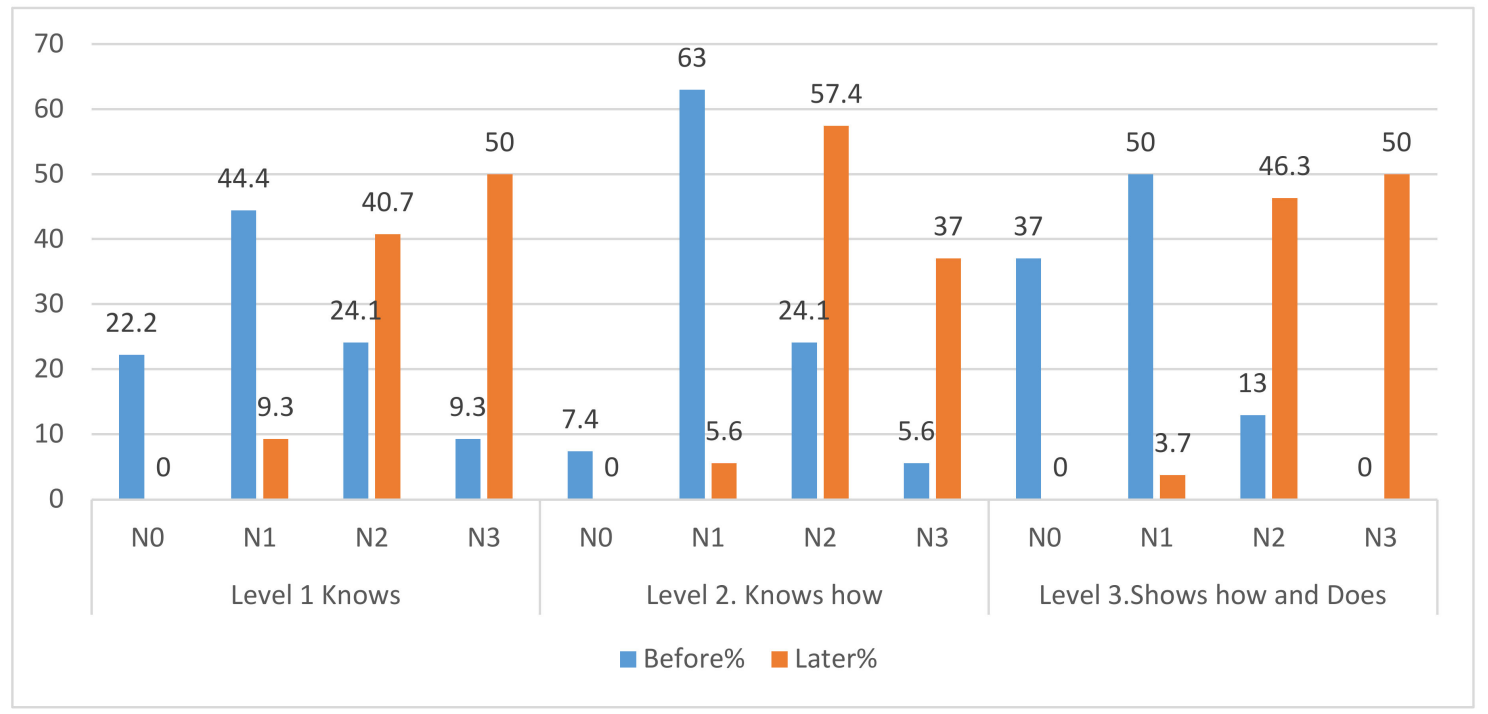

Figure 5. SUST 4-Application of ethical principles related to sustainability values in personal and professional behavior.

Regarding Level 2, which measures the degree of acquisition of the learning outcome "Analyzes and understands the relationship between natural systems and social and economic systems and how climate change influences them", $83.4 \%$ are located at levels NO and N1 before the experience. After their participation, $100 \%$ of the students are in N2 and N3, with N2 being eight percentage points higher than N3.

For Level 3, which measures the degree of acquisition of the learning outcome "Is able to imagine and predict the impacts the climate change produces in natural, social and economic systems", initially $92.6 \%$ of the students are in levels N1 and N2, this initial percentage is the highest of all the competitions. After participating in the experience, $98.1 \%$ of PPT were located between N2 and N3. The jump in N3 is especially significant, going from $1.9 \%$ to $83.3 \%$.

Figure 3 shows how in Level 1 corresponding to the competence unit "Knows the procedures and resources to integrate sustainability into educational projects", before starting the educational experience, $77.8 \%$ of PPT acknowledge being in the N1. After the educational experience, the N1 is reduced to $3.7 \%$, placing the PPT at higher levels: N2 (40.7\%) and N3 (55.6\%). 
In relation to Level 2 "Understands and takes advantage of the opportunities that present themselves in educational contexts in order to plan sustainable projects", before the experience, 59.3\% of the PPTs admit to being in the N1. However, after the educational experience, no PPT are found at the lower levels (N0 and N1), the PPT only reach higher levels N2 (46.3\%) and N3 (53.7\%)

Finally, before the experience, the Level 3 corresponding to the competence unit "Provides critical and creative solutions from an educational project to the problem of Climate change", half of the PPT are located in an N2. After the educational experience, the increase in N3 stands out: from 1.9\% (before the experience) to $61.1 \%$ (after the experience)

Figure 4 shows as in Level 1, which measures the acquisition level of the learning outcome "Has basic knowledge of identifying possible socio-environmental impacts derived from educational actions", highlights how more than $50 \%$ were initially found in N1. After the experience, $50 \%$ were in $\mathrm{N} 2$ and $44.4 \%$ in N3, however, no student was in N3 before the experience.

Regarding the Level 2 learning outcome "Knows how to develop educational actions that mitigate negative socio-environmental impacts", $50 \%$ of the students acknowledge being in N1 and none in N3 before the experience. After their participation, it stands out how more than half of the students recognize themselves to be at the high level N3.

Regarding the Level 3 learning outcome "Designs and develops educational activities in which negative socio-environmental impacts are taken into account and incorporates mitigating measures", it is highlighted how $31.5 \%$ of the students recognize that they had not acquired this level of competence before the experience. However, they declare that half are in N2 and $48.1 \%$ in N3 after the development of the teaching proposal. It is striking how no student was placed in N3 before the experience and how after the experience no student was located in N1.

In Figure 5 we can see how in relation to Level 1 learning outcome "Knows the ethical principles of sustainability and the importance of respecting diversity in educational intervention", more than half of the students acknowledge being in N0 or N1 before the didactic intervention. After their participation, half of the students were in a high grade N3 and $40.7 \%$ in a medium grade N2.

Regarding the Level 2 learning outcome "Understands and integrates the ethical principles of sustainability in his/her actions, considering nature as good in itself and transmitting the importance of education for a change in the relationship between human beings and the partner-cultural environment", it is striking how $63 \%$ acknowledge having a low degree of acquisition of this learning outcome before participating in the experience. It is also striking that the N3 is not the highest level after participation with a difference of twenty percentage points. These data reveal that it is a learning outcome to be reinforced in future interventions.

The Level 3 learning outcome "The ability to design and/or manage educational projects taking into account ecological ethics to improve the quality of life and promote the common good", highlights that $87 \%$ of students recognize themselves in a N0 and a N1 before the experience which showed a great jump towards levels $\mathrm{N} 2$ and $\mathrm{N} 3$ after the teaching intervention. It is relevant that initially no student was located in N3 and that after the experience $50 \%$ of the students were located in this category.

\section{Discussion}

The learning outcome "Is able to imagine and predict the impacts the Climate change produces in natural, social and economic systems" (Sust1.1 Level3 N3) experiences an important increase of 81.4\% of PPT who declare to have acquired this learning outcome at a high level.

In the Berkhout, Hertin and Jordan studies [56] the authors state that in order to improve skills in the perception of the impacts on Climate change, one should also work with analytical data, participate in processes of social and organizational learning. This would require developing tools that can stimulate and improve processes of learning - by setting the frame for iterative processes of self-reflection, change and adaptation.

Regarding the learning outcome "Provides critical and creative solutions from an educational project to the problem of Climate change" (Sust1.2 Level3 N3), it experienced an increase of 59.2\%. 
From research in the field of sustainability, we predict the development of competences in which PPT feel capable of providing solutions to socio-environmental problems [57] in which the critical approach to sustainability is essential [58].

In relation to the learning outcome "Knows how to develop educational actions that mitigate negative socio-environmental impacts" (Sust2 Level2 N3), there was an increase of 59.3\%. It is interesting how in this learning outcome before their participation in the experience, no PPT felt capable of carrying out educational actions aimed at mitigating climate change. Developing sustainability competencies should train future teachers for action. Along the lines of Sanmartí and Pujol [59], educators must be prepared for the development of educational actions that provide solutions to socio-environmental problems.

Another of the learning outcome to highlight is "Designs and develops educational activities in which negative socio-environmental impacts are taken into account and incorporates mitigating measures" (Sust2 Level 3N) since before the experience there was no student who recognized having a high level of this competition. After participating in the teaching proposal, $48.1 \%$ acknowledge having acquired it at a high level. It is important that PPT feel empowered to be able to reduce environmental impacts with their educational intervention [23].

In this sense, one of the proposals to deepen the development of this competence is aimed at preparing sustainability reports for the PPT Dissertation [54], a project that is being developed within the framework of the EDINSOST2 project for future proposals.

The learning outcome "Is able to design and/or manage educational projects taking into account ecological ethics to improve quality of life and to promote the common good" (Sust4 Level3 N3) stands out for not finding any student at this level before the experience. After the experience, $50 \%$ of the PPT reached this level. It is an outstanding fact to highlight the importance of environmental ethics [60-62] in the design and management of educational projects in order to improve quality of life, and how half of the PPT feel prepared to incorporate these criteria in their teaching activity.

On the other hand, it is necessary to read those learning outcomes that have not reached the maximum level (N2 is greater than N3) in order to improve them. For example, the competition: "Understands and takes advantage of the opportunities that present themselves in educational contexts in order to plan sustainable projects" (Sust1.1 Level2). The N2 are 53.7\% and the N3 46.3\% of the students. As for this learning outcome, it may require more experiences throughout your teaching career to achieve better levels from the educational proposal made. That is why this learning outcome is proposed together with the Sust2 Level $3 \mathrm{~N}$ as learning outcome that need a more global development for the Dissertation subject.

Regarding the learning outcome "Has basic knowledge of identifying possible socio-environmental impacts derived from educational actions" (Sust2 Level1) in N2 there are 50\% and 44.4\% in N3. In addition, $5.6 \%$ of PPT declare to have a low level of this learning outcome. These data indicate the need to reinforce content related to this competition, since this learning outcome with lower values achieved.

Regarding the learning outcome "Understands and integrates the ethical principles of sustainability in his/her actions, considering nature as a good in itself and transmitting the importance of education for a change in the relationship between human beings and the socio-cultural environment" (Sust4 Level2), $57.4 \%$ of the PPT declared an average level of N2 while $37 \%$ were in N3. In addition, $5.6 \%$ of students claimed to have a low level of this learning outcome. Integrating the ethical principles of sustainability into actions is a difficult task due to overcoming the gap between thought and action. Many sustainability training programs are dedicated to working with the first part (thought) and training in awareness, but the difficulty lies precisely in the change of habits and attitudes for sustainability [29].

Finally, another of the learning outcomes that needs reinforcement is "Knows the ethical principles of sustainability and the importance of respecting diversity in educational intervention" (Sust4 Level 1) since there are $9.5 \%$ of PPT in relation to this outcome who, after the experience, continue to be located 
in a N1, so the teaching proposal can improve in line with the deepening of ethical principles of sustainability in teacher training [63].

\section{Conclusions}

In this work, we present the results of an innovative teaching proposal and its educational implication regarding their degree of acquisition of competencies in sustainability (before and after their participation in the teaching experience).

Regarding teaching experience, we got four different products as a result of the whole educational process (prior knowledge questionnaire on climate change, a rubric; report about the main primary school students' prior knowledge and educational proposals on climate change). These products are gotten from a participatory and active methodology. PPT have been involved in the entire educational process, designing, proposing and arguing every single decision in order to design a teaching lesson on climate change.

Regarding teaching implications, we focus on the self-perception of PPT about their degree of acquisition of competencies in sustainability. In general, data indicate that students have a positive perception regarding their level of achievement. However, we have detected other lesser levels of achievement. Both cases are important to contemplate in order to enhance the formative curriculum based on interdisciplinary educational proposals. For that, it is necessary to work from different areas of knowledge across the teachers' formation. Moreover, this approach to the phenomenon from the PPT self-perceptions about Climate change allows us to reflect on the important environmental worldviews and their perception [44].

This work, in addition to addressing the main research question, allows us to assess the level of sustainability of our subject based on the educational proposal designed. Consequently, the results obtained from the self-perception of the level of achievement of sustainability competencies by our PPT, indirectly indicate the positive level of sustainability of our subject. These issues are being worked on in the continuation EDINSOST2-ODS (2019-2022) project "Integration of Sustainable Development Objectives in sustainability training in Spanish university qualifications".

\section{Limitations of the Study}

We have to point out some limitations of this research. On the one hand, we approach the level of achievement of competence in sustainability from the self-perception of the PPT. Therefore, the study would be more complete by crossing the data with the evaluation by the teacher, which for reasons of length we have not addressed in this work. On the other hand, after this research, we have become aware of the importance of other factors to be considered in the development of sustainability competencies, such as the environmental worldview of PPT and its relationship with perception, as other studies indicate [44]. Nonetheless, this research is a case study and a first approach to the phenomenon, thus we have to delve deeper into this issue.

Author Contributions: Conceptualization, Methodology, Validation, Investigation, Resources, Writing-Review and Editing, Visualization, C.S.-E. and H.M.-M.; Data Curation, Writing Original Draft Preparation, Project Administration, C.S.-E. All authors have read and agreed to the published version of the manuscript.

Funding: This research was funded by the EDINSOST Project "Education and Social Innovation for Sustainability. Training at Spanish universities of professionals as agents of change to face the challenges of society", funded by the "R\&D State programme oriented towards the challenges facing society" of the Spanish Ministry of Economy and Finance [Ref. EDU 2015-65574-R] and which continues with EDINSOST2-ODS (2019-2022) "Integration of Sustainable Development Objectives in sustainability training in Spanish university qualifications" [Ref. EDU RTI2018-094982-B-100].

Conflicts of Interest: The authors declare no conflict of interest. 


\section{References}

1. Vega-Marcote, P.; Varela-Losada, M.; Álvarez-Suárez, P. Evaluation of an educational model based on the development of sustainable competencies in basic teacher training in Spain. Sustainability 2015, 7, $2603-2622$. [CrossRef]

2. Muñoz-Rodríguez, J.M.; Sánchez-Carracedo, F.; Barrón-Ruiz, A.; Serrate-González, S. Are We Training in Sustainability in Higher Education? Case Study: Education Degrees at the University of Salamanca. Sustainability 2020, 12, 4421. [CrossRef]

3. Gimeno Sacristán, J. Educar por Competencias, qué Hay de Nuevo; Morata: Madrid, Spain, 2008.

4. Tenorth, H.E. La problemática de los estándares de formación y sus exámenes. Profr. Rev. Curric. Form. Profr. 2009, 13, 1-17.

5. Morón, H.; Muñoz, G. Una mirada crítica hacia los objetivos y competencias en los libros de texto de ciencias: Una propuesta didáctica para la formación de maestros. Rev. Currículum Form. Profesorado. 2018, 22, $493-507$.

6. Organisation For Economic Co-Operation and Development. Annual Report 2002; OECD: Paris, France, 1995.

7. Heyworth, F. The common European framework. ELT J. 2006, 60, 181-183. [CrossRef]

8. López, M.C.L.; Navas, J.J.L.; Trujillo, A.L.; Merino, D.S.; Sánchez, M.T. La educación comparada en el marco del Espacio Europeo de Educación Superior: Una propuesta desde la innovación docente. In Handbook of Educación Como Respuesta a la Diversidad: Una Perspectiva Comparada; Universidad Pablo de Olavide: Sevilla, Spain, 2008; pp. 154-155.

9. Pedrinaci, E.; Caamaño, A.; Cañal, P.; De Pro, A. 11 Ideas Clave: El Desarrollo de la Competencia Científica; Grao: Barcelona, Spain, 2012.

10. Donnelly, J.; Ryder, J. The pursuit of humanity: Curriculum change in English school science. Hist. Educ. 2011, 40, 291-313. [CrossRef]

11. Blanco, A.; España, E.; Rodríguez, F. Contexto y enseñanza de la competencia científica. Alambique Didáctica Cienc. Exp. 2012, 70, 9-18.

12. De la Caba Collado, M.Á.; Atxurra, J.R.L. Actividades de participación y desarrollo de competencias de ciudadanía en los libros de texto de educación primaria de la comunidad autónoma vasca (conocimiento del medio). Rev. Educ. 2005, 336, 377-396.

13. De Pro Bueno, A. De la enseñanza de los conocimientos a la enseñanza de las competencias. Alambique Didáctica Cienc. Exp. 2007, 53, 10-21.

14. Mesa, R. Evaluar competencias básicas. In I Congreso de Inspección de Andalucía: Competencias Básicas y Modelos de Intervención en el Aula. Revistas de la Universidad de Granada 2010, 53, 493-507.

15. Morón, H.; Morón, M.C. El Patrimonio Natural y Científico tecnológico para el desarrollo de la competencia científica: Análisis en los libros de texto de Ciencias de la Naturaleza para Educación Secundaria. In Handbook of I Congreso Internacional El Patrimonio Cultural y Natural Como Motor de Desarrollo: Investigación e Innovación; UNIA: Sevilla, Spain, 2012; pp. 1656-1669.

16. Sáiz Serrano, J. El tratamiento de las competencias básicas en los actuales libros de texto de historia en secundaria. Limitaciones y propuestas de mejora. Íber Didáctica Cienc. Soc. Geogr. Hist. 2013, 74, 52-61.

17. Sáiz Serrano, J. Actividades de libros de texto de Historia, competencias básicas y destrezas cognitivas, una difícil relación: Análisis de manuales de $1^{\circ}$ y $2^{\circ}$ de ESO. Didáctica Cienc. Exp. Soc. 2013, 24, 37-64.

18. Cebrián, G.; Fernández, M.; Fuertes, M.T.; Álvaro, M.; Segalàs, J. La influencia del aprendizaje-servicio en el desarrollo de competencias en sostenibilidad en estudiantes universitarios. Bordón. Revista De Pedagogía 2019, 71, 151-167.

19. UNESCO. Diálogo Entre Civilizaciones. 2002. Available online: https://es.unesco.org/courier/enero-2004 (accessed on 10 April 2020).

20. Carracedo, F.S.; Segalàs, J.; Cabré, J.; Climent, J.; López, D.; Martín, C.; Vidal, E. El proyecto EDINSOST: Inclusión de los ODS en la educación superior. Revista Española de Desarrollo y Cooperación 2017, 41, 67-81.

21. Ferrer Carbonell, E.; Lazo Machado, C.J.; Conde, P. Universidad y desarrollo sostenible. Revista Pedagogía Universitaria. 2004, 9, 3.

22. Penagos, W.M.M. Educación ambiental y educación para el desarrollo sostenible ante la crisis planetaria: Demandas a los procesos formativos del profesorado. Tecné Epistem. Didaxis 2009. [CrossRef]

23. Murga-Menoyo, M.A. Competencias para el desarrollo sostenible: Las capacidades, actitudes y valores meta de la educación en el marco de la Agenda global post-2015. Foro Educación. 2015, 13, 55-83. [CrossRef] 
24. Verdera, V. El aprendizaje-servicio: Una estrategia para la formación de competencias en sostenibilidad. Foro Educación. 2015, 19, 193-212. [CrossRef]

25. Aramburuzabala, P.; Cerrillo, R.; Tello, I. Aprendizaje-servicio: Una propuesta metodológica para la introducción de la sostenibilidad curricular en la universidad. Profr. Rev. Curric. Form. Profr. 2015, 19, 78-95.

26. Novo, M.; Murga-Menoyo, M. The processes of integrating Sustainability in Higher Education Curricula: A theoretical-practical experience regarding key competences and their cross-curricular incorporation into degree courses. In Handbook of Transformative Approaches to Sustainable Development at Universities; Springer: Cham, Switzerland, 2015; pp. 119-135.

27. Azcárate, M.P.; Navarrete, A.; García González, E. Aproximación al nivel de inclusión de la sostenibilidad en los curricula universitarios. Profr. Rev. Curric. Form. Profr. 2012, 16, 105-119.

28. Manzanares, M.; Fuentes, A.; Manzanares, M.C. Diseño y Desarrollo de una unidad didáctica sobre desarrollo sostenible en maestros de educación primaria. Res. Novae Cordubenses Estud. Calid. Innovación Univ. Córdoba. 2006, 4, 227-257.

29. Albareda-Tiana, S.; García-González, E.; Jiménez-Fontana, R.; Solís-Espallargas, C. Implementing pedagogical approaches for ESD in initial teacher training at Spanish Universities. Sustainability 2019, 11, 4927. [CrossRef]

30. Saenz-Rico, B.; Benitez, L.; Neira, J.M.; Sobrino, M.R.; Mendez, E. Perfiles profesionales de futuros maestros para el desarrollo sostenible desde un modelo formativo centrado en el diseño de ambientes de aprendizaje. Foro Educ. 2015, 13, 141-163. [CrossRef]

31. Cebrián, G.; Junyent, M. Competencies in education for sustainable development: Exploring the student teachers' views. Sustainability 2015, 7, 2768-2786. [CrossRef]

32. Cantó, J. Percepción de la sostenibilidad en los maestros en formación de educación infantil. Indagatio Didact. 2016, 8, 96-109.

33. Shor, I. Empowering Education: Critical Teaching for Social Change; The University of Chicago Press: Chicago, IL, USA, 1992.

34. Hilário, T.; Reis, P. Potencialidades e limitações de sessões de discussão de controvérsias sociocientíficas como contributos para a literacia científica. Rev. Estud. Univ. 2009, 35, 167-183.

35. Reis, P. Acción socio-política sobre cuestiones socio-científicas: Reconstruyendo la formación docente y el currículo. Uni-Pluri Versidad. 2014, 14, 16-26.

36. Ratcliffe, M.; Grace, M. Science Education and Citizenship: Teaching Socio-Scientific Issues; Open University Press: Buckingham, UK, 2003.

37. Sadler, T.D. Informal reasoning regarding socioscientific issues: A critical review of research. J. Res. Sci. Teach. 2004, 41, 513-536. [CrossRef]

38. Sadler, T.D. Moral and ethical dimensions of socioscientific decision-making as integral components of scientific literacy. Sci. Educ. 2004, 13, 39-48.

39. Zeidler, D.L.; Sadler, T.D.; Simmons, M.L.; Howes, E.V. Beyond STS: A research based framework for socioscientific issues education. Sci. Educ. 2005, 89, 357-377. [CrossRef]

40. Hodson, D. Becoming part of the solution: Learning about activism, learning through activism, learning from activism. In Handbook of Activist Science and Technology Education; Springer: Dordrecht, The Netherlands, 2014; pp. 67-98.

41. Marqués, A.R.; Reis, P. Producción y difusión de vídeos digitales sobre contaminación ambiental. Estudio de caso: Activismo colectivo basado en la investigación. Rev. Eureka Sobre Enseñanza Divulg. Cienc. 2017, 14, 215-226.

42. Hodson, D. Time for action: Science education for an alternative future. Int. J. Sci. Educ. 2003, 25, 645-670. [CrossRef]

43. COSCE. Informe Enciende: Enseñanza de las Ciencias en la Didáctica Escolar Para Edades Tempranas en España; Rubes Editorial: Madrid, Spain, 2011.

44. Ramkissoon, H.R.; Smith, L.D.G. The relationship between environmental worldviews, emotions and personal efficacy in climate change. Int. J. Arts Sci. 2014, 7, 93-103.

45. Ramkissoon, H.; Mavondo, F.; Uysal, M. Social involvement and park citizenship as moderators for quality-of-life in a national park. J. Sustain. Tour. 2018, 26, 341-361. [CrossRef]

46. Aguirre, J.M.; Haggerty, S.M.; Linder, C.J. Student teachers conceptions of science, teaching and learning: A case study in preservice science education. Int. J. Sci. Educ. 2007, 12, 381-390. [CrossRef] 
47. González, G.T.; Estrada, F.J.P. Enseñar economía mediante estrategias de investigación escolar: Estudio de caso sobre las concepciones y prácticas del profesorado. Enseñanza Cienc. Soc. Rev. Investig. 2008, 7, 109-120.

48. Mariscal, A.J.F. Competencias científicas en la enseñanza y el aprendizaje por investigación. Un estudio de caso sobre corrosión de metales en secundaria. Enseñanza Cienc. Rev. Investig. Exp. Didácticas. 2015, 1, 231-252.

49. García-Carmona, A. Pre-service primary science teachers' abilities for solving a measurement problem through inquiry. Int. J. Sci. Math. Educ. 2019, 17, 1-21. [CrossRef]

50. Albareda-Tiana, S.; Goded, P.A.; Muñoz-Rodríguez, J.M.; Valderrama-Hernández, R.; Ruiz-Morales, J. Evaluar competencias en sostenibilidad en los grados y posgrados de educación: Propuesta de un instrumento. Enseñanza Cienc. 2019, 37, 11-29.

51. Solís-Espallargas, C.; Ruiz-Morales, J.; Limón-Domínguez, D.; Valderrama-Hernández, R. Sustainability in the University: A Study of Its Presence in Curricula, Teachers and Students of Education. Sustainability 2019, 11, 6620. [CrossRef]

52. Sánchez-Carracedo, F.; Ruiz-Morales, J.; Valderrama-Hernández, R.; Muñoz-Rodríguez, J.M.; Gomera, A. Analysis of the presence of sustainability in Higher Education Degrees of the Spanish university system. Stud. High. Educ. 2019, 1-18.

53. Sáiz, M.S.I.; Gómez, G.R.; Ruiz, M.Á.G. La evaluación entre iguales: Beneficios y estrategias para su práctica en la universidad1 Benefits of Peer Assessment and Strategies for Its Practice at University. Revista de educación 2012, 359, 6-23.

54. Albareda-Tiana, S.; Ruíz-Morales, J.; Azcárate, P.; Valderrama-Hernández, R.; Múñoz, J.M. The EDINSOST project: Implementing the sustainable development goals at university level. In Universities as Living Labs for Sustainable Development; Springer: Cham, Switzerland, 2020; pp. 193-210.

55. Miller, G.E. The assessment of clinical skills/competence/performance. Acad. Med. 1990, 65 (Suppl. 9), 63-67. [CrossRef]

56. Berkhout, F.; Hertin, J.; Jordan, A. Socio-economic futures in climate change impact assessment: Using scenarios as 'learning machines'. Glob. Environ. Chang. 2002, 12, 83-95. [CrossRef]

57. Stagell, U.; Almers, E.; Askerlund, P.; Apelqvist, M. What Kind of Actions Are Appropriate? Eco-School Teachers and Instructors Ranking of Sustainability-Promoting Actions as Content in Education for Sustainable Development (ESD). Int. Electron. J. Environ. Educ. 2014, 4, 97-113. [CrossRef]

58. Kearins, K.; Springett, D. Educating for sustainability: Developing critical skills. J. Manag. Educ. 2003, 27, 188-204. [CrossRef]

59. Sanmartí, N.; Pujol, R.M. Qué comporta" capacitar para la acción" en el marco de la escuela? Investig. Esc. 2002, 46, 49-54.

60. Sosa, N.M. La ética en la Educación Ambiental. In Educación ambiental: Sujeto, entorno y sistema; Amarú: Salamanca, Spain, 1995; pp. 140-163.

61. Kronlid, D.O.; Öhman, J. An environmental ethical conceptual framework for research on sustainability and environmental education. Environ. Educ. Res. 2013, 19, 21-44. [CrossRef]

62. Sánchez Carracedo, F.; García Almiñana, J.; Vidal López, E.M.; López Álvarez, D.; Cabré Garcia, J.M.; García García, H.; Martín Escofet, C. Es sostenible la Estrella de la Muerte? ReVisión 2015, 8, 81-103.

63. Solís-Espallargas, C.; Valderrama-Hernández, R. La educación para la sostenibilidad en la formación de profesorado ¿ Qué estamos haciendo? Foro de Educación 2015, 13, 165-192.

(C) 2020 by the authors. Licensee MDPI, Basel, Switzerland. This article is an open access article distributed under the terms and conditions of the Creative Commons Attribution (CC BY) license (http://creativecommons.org/licenses/by/4.0/). 